\title{
Rural tourism as alternative for sustainable development case Huichapan, Hidalgo, Mexico.
}

\author{
Turismo Rural como alternative para el desarrollo sustentable caso Huichapan, Hidalgo, \\ México.
}

\author{
Nancy Testón Franco ${ }^{a}$, Carolina García Zamudio ${ }^{\mathrm{b}}$
}

\begin{abstract}
:
Rural tourism is a dynamic and innovative way of doing tourism, because it is very different from the traditional sun and beach tourism that is better known, the latter focuses on the tourist area of a place with a beach leaving aside the receiving community; However, the rural one focuses on the less privileged towns but with great tourist potential, to develop the tourist activity in which the tourist enters in contact with nature, the receiving community and its culture, as long as the heritage is preserved and the environment is taken care of, since a characteristic of this one, is that a sustainable development is carried out, in which besides knowing the customs and traditions of a place also the natural environment is preserved. It is worth mentioning that this activity is gaining strength day by day, since it is considered a way to eradicate poverty from a site, due to the great economic spill it generates.
\end{abstract}

\section{Keywords:}

Rural tourism, tourism potential, sustainability

\section{Resumen:}

El turismo rural es una forma dinámica e innovadora de hacer turismo, porque es muy diferente del turismo tradicional sol y playa que es mejor conocido, este último se centra en la zona turística de un lugar con una playa que deja de lado la comunidad receptora; Sin embargo, el rural se centra en las ciudades menos privilegiadas, pero con gran potencial turístico, desarrollar la actividad turística en la que el turismo entra en contacto con la naturaleza, la comunidad receptora y su cultura, siempre que se mantenga el patrimonio y el medio ambiente, dado que una característica de este, es que se lleva a cabo un desarrollo sostenible, en el que además se conocen las costumbres y tradiciones de un lugar también se conserva el medio natural. Cabe mencionar que esta actividad está ganando fuerza día a día, ya que se considera una forma de erradicar la pobreza de un sitio, debido al gran derrame económico que genera.

\section{Palabras Clave:}

Turismo Rural, potencial turístico, sustentabilidad

\section{Introduction}

Over the past few years, rural tourism has been taking greater force within the tourism industry, with a view to giving tourism a plus to tourism, as well as to benefit the less resources communities but with a great tourist attraction that can be used.

In this way rural tourism provides tourist with an experience of making public awareness and interacting with the customs and traditions of a people and not harming it, that is when sustainability comes in and goes hand in hand with rural tourism, since without mediumterm care, it could not be possible, since it is about benefiting the population rather than affecting it in every way.

For the World Tourism Organization, "rural tourism is a type of tourism activity in which the visitor's experience relates to a wide spectrum of products generally linked to activities of nature, agriculture, life forms and rural cultures, cane fishing and visiting places of interest" [1]. 
Tourism is also a factor that is economically active in rural communities through intervention by the recipient community with tourism service providers in an organized and viable manner in which everyone gains an emphasis on the local population.

The present investigation aims to identify the tourist potential in the rural segment by drawing up a catalogue of resources to enable the design of tourist routes to increase tourism activity in the region, in the municipality of Huichapan Hidalgo. The municipality has the magic people's name. In this place we can find a variety of attractive that can be easily feasible for the development of rural tourism at the site.

\section{Conceptual and theoretical research}

Tourism is a promising activity that provides an opportunity to generate a change in the area where it is worked, this is a viable development tool for improving the place as well as its economy. For this reason, because of the economic potential of tourism, new ways of making and innovate tourism have been sought, turning to the rural communities, where we find a new diversity of tourism supply.

The implementation of tourist activities in rural areas has high expectations, as it promises to generate a change and benefit the recipient community. Tourism, for its part, is a means of access to the community with the outside and access to sustainable alternatives where the place is not damaged. Kieffer (2017:12) mentioned, the development action that is given by the presence of extreme basic necessity, then aims to strengthen existing social structures in communities, becoming a global negotiating/conciliation process. The comprehensive approach to development leads to the inclusion of the various actors involved in the social construction process of tourism activity. Indeed, if we extend the problem to social, cultural, political, environmental and economic sectors, it is the synergies created among them which become essential to generate a process of social change from the base.

In order to achieve comprehensive development, the local population must have community participation in all the development of planning processes and also assume the responsibility involved.

The World Tourism Organization (UNWTO) also defines rural tourism as, a type of tourism activity in which the visitor's experience relates to a wide spectrum of products generally linked to activities of nature, agriculture, life forms and rural cultures, cane fishing and visiting places of interest. Rural tourism activities are carried out in nonurban (rural) environments with the following characteristics:

1. Llow demographic density

2. Landscapes and territorial planning where agriculture and forestry prevail,

3.Social structures and traditional life forms[1].

Moreover, the development of tourism in rural areas must promote the resolution of sociocultural and economic problems that benefit the population and improve their quality of life. Rural tourism also focuses on the conservation of natural and cultural resources, which through the involvement of the local community can be safeguarded by ensuring their conservation and care.

This form of tourism is a tool to combat poverty. However, it has negative effects that are contrary to what is focused, for example pollution and deterioration of culture, which is why rural tourism is carefully planned and implemented in a detailed manner so as to avoid negative impacts in carrying out activities and to obtain benefits for destination. In addition, the interest of rural areas in the conduct of tourism activities is focused on natural spaces where there are spaces with little influx of people.

This form of tourism is a tool to combat poverty. However, it has negative effects that are contrary to what is focused, for example pollution and deterioration of culture, which is why rural tourism is carefully planned and implemented in a detailed manner so as to avoid negative impacts in carrying out activities and to obtain benefits for destination. In addition, the interest of rural areas in the conduct of tourism activities is focused on natural spaces where there are spaces with little influx of people.

It is therefore very important to plan carefully the rural tourism project that is desired in the community, otherwise the exchange rate would not have any benefit, since the activity would be over very short time. A long-term vision needs to be considered and taken of the culture of the community, as well as its participation in activities, so that they are not changing, otherwise the tourist resource would be over. In addition to maintaining its lifestyle in a way that is not altered, as tourism would be a complementary activity on a daily basis.

This is how rural tourism is presented in a way that broadening and diversifying productive activities within the community. In wanting to implement tourist activities at a particular place, it is necessary to consider various factors such as infrastructure and loading capacity of the site, and more if it is a rural destination, as more attention must be given to these. According to the Foundation of 
the Urgent Spanish (Fundéu), "substantive tourism is a well-trained term, referring to the impact of tourism massification on the commercial and social fabric of certain neighborhoods or cities." [2].

Meanwhile, culture should be conceptualized as a process of identity building and responses to present and future challenges. The importance of the non-utilitarian role of culture, the wealth of cultural exchanges and sociality would help to reduce cultural impoverishment often generated by tourism and the production of cultural enrichment that should allow tourism to be used as an occasion for cultural approaches [3]

Sustainable development under the World Commission on Environment and Development is, "sustainable development refers to the capacity developed by the human system to meet the needs of current generations without compromising resources and opportunities for future generations for growth and development" [4].

So, sustainability has been increasingly assumed within tourism, however, in Mexico, it has not been possible to achieve a level, since the instruments are limited in environmental issues. Sustainable practices that have been carried out occur by following rules or policies that are imposed, or that companies find advantages such as costs or improvement of structures depending on demand for the tourist market and not so much on environmental concerns [1].

\section{Rural tourism in the world}

The concept has gained greater strength around the world, making different countries worldwide interest in rural tourism, as a path of economic development for the most needy communities with great tourism potential.

In large measure rural tourism has been driven by Europe because of the interest in seeking methods that reactivate the economy, which is attempted to curb the serious exoduses which led to imbalances between rural and urban areas.

Javier Solsona (2006) señala que, dentro de la política agraria de la Unión Europea se establecieron programas orientados específicamente al turismo rural, mediante ayudas para inversiones en aquellas explotaciones en las que la actividad principal fuese agrícola o en las que sin ser agricultores principalmente se obtuviese al menos un $50 \%$ de la renta a partir de actividades agrícolas, forestales, turísticas, artesanales o de actividades relacionadas con la conservación del espacio natural.
Similarly, Community tourism is a new tourism mode being developed in Latin America as an alternative to mass tourism. This tourist typology allows environmental conservation and involvement of the local community in tourist management of the territory. Such tourism is a key tool for reducing the poverty level of the most depressed areas, contributing to their economic growth and reducing migration [6].

\section{Rural tourism in Mexico}

In the case of Mexico, an agricultural policy has been promoted, with which the levels of poverty among rural populations, living in conditions of exclusion, have been increased socially, since they face severe difficulties as a result of the agricultural and productive problems of recent years. Against this, peasants seek survival strategies such as rural tourism, which represents an option for promoting local development. This is the case, that this type of tourism becomes an activity generated by communities, based on their forms of cultural organization and participation in various activities [7].

Similarly, as mentioned in the article of Sustainable Community Tourism in the Microregion, Guerrero, Mexico: One of the countries considered the pioneer in the development of tourism in communities is Ecuador, through the application of methodologies that have benefited positively from rural areas, since it has achieved use through: job creation, decreased rural migration, improving the quality of life and generation of extra income without populations leaving their main sources of income [8].

Moreover, the Government of Morelos has developed attention to rural tourism at the facilities of the Chalcatzingo community in the municipality of Jantetelco, where a collaborative agreement was signed between the Tourism and Culture Secretariat (STyC) and the Institute for Training for Labor in the State of Morelos (ICATMOR), for training and technical assistance in community projects in rural tourism and ecotourism [9].

In this respect, efforts to develop rural tourism in Mexico are growing, because it is an alternative to the development of a site, especially today, which requires the revival of tourism worldwide and better start with marginalized communities.

\section{Rural tourism in Hidalgo}

Hidalgo is located in the Central Region of Mexico and is one of the most offered states and opportunities for 
adventure tourism. Its Mountain Runner offers various destinations and climates and ecosystems where cabins, hotels, ecotourist shelters and adventure tourism operators exist (Adventure México, 2019). In addition to having a privileged location connecting with states such as Querétaro and State of Mexico.

In the Ixmiquilpan region, there is a small community that has grown and has learned to benefit rural tourism, the rural community El Alberto, which has managed to build two productive units: the basic management unit of tourism services and a water company, which constitutes the Eco-Alberto cooperative, which operates as a community social company. The incorporation of the population into tourism work has not changed their customs and identity, remain a rural group, whose economy and organization project is aimed at improving their lives. The origin of visitors is mainly from the Federal District, 34 per cent, Mexico State 30 per cent, Querétaro 4 per cent, Veracruz 3 per cent, Morelos 4 per cent, Puebla 5 per cent, Hidalgo 12 per cent, foreign origin: 3 per cent, Canada 3 per cent, Spain 1 per cent and Italy 1 per cent, the benefits that are derived from the entire population and are added to favor the environment, image and status of their property and territory, of which they have power and control, as they have now generated safer and dignified labor sources [7]

According to the above-mentioned authors, "In this regard, the development of tourism activity has been gradually presented; this has enabled the population to be administered and organized according to the growth and requirements of visitors, to diversify and ensure the supply of services. Since 2003, the largest influx of tourists took place at the holy weekend, weekends and holiday periods [7]

It is therefore important to stress how important it is for rural tourism to move forward and take the mayor force in the state of Hidalgo, because it is a state, in which the economy is no safer.

The Organization for Economic Cooperation and Development (OECD) recommends in its presentation of the "Hidalgo Territorial Study", to develop a long-term strategy for entrepreneurial development in rural areas, through promoting the use of new agricultural technologies capable of increasing productivity and diversification of the rural economy, for example by further enhancing the tourism sector. Such a strategy should focus on improving the capacities and support programs for entrepreneurs in rural areas, increasing access to public services through ICT use and fostering connectivity in the north of the state, through improving infrastructure and partnerships with other states [10].

\section{Tourism in Huichapan}

The municipality of Huichapan, which is known as the website of the State of Hidalgo, which speaks of its strategic and privileged location can lead to displacement within the state and others ; as from 2012, it was appointed magic people by the tourism secretary, resulting from the appointment received by the municipality in 2012 as "Magic People" by the Tourism Secretariat, this is thanks to its cultural, historical, architectural and culinary wealth, which it has resulted in strengthening the supply of tourism in the region, however, has not achieved a profit and an infrastructure in the non-solidified community and the local community has not been economically or socially for this appointment.

The main sectors, products and services relate to the following aspects: quarry removal and processing, agriculture, livestock, industry and trade, and tourism activity is at post 5 for the municipality's income [11].

According to the Annual Report on the Poverty and Social Rezago Social, in the sociodemographic indicators section, the total population of the municipality in 2010 was 44.253 , representing 1.7 per cent of the population in the state. In the same year, 11.002 households (1.7 per cent of total households in the entity) were headed by heads of households ( 1.6 per cent of the total entity).

In 2010 , the municipality had 50 pre-school schools (1.5 per cent of the State total), 44 primary schools (1.4 per cent of the total) and 18 secondary schools ( 1.5 per cent). In addition, the municipality had five baccalaureates (1.8 per cent) and three training schools for work (2.4 per cent). The municipality also had two indigenous primaries (0.3 per cent). Medical units in the municipality were 19 (2 per cent of the total medical units in the state. 27.181 individuals (57.8 per cent of the total population) were in poverty, 22.710 (48.3 per cent) were in moderate poverty and 4.471 (9.5 per cent) were in extreme poverty In 2010 , the status of education was affected by 24 per cent of the population, which means that 11,284 individuals had this social deficiency. The percentage of individuals reporting to inhabit dwellings with poor material and insufficient space was 8.8 per cent (4.125 persons). The percentage of persons reporting to reside in housing without availability of basic services was 30.5 per cent, which means that housing conditions are not adequate for 14.337 persons [12].

One of the main means of communication is the MexicoQuerétaro highway, which connects Huichapan to the 
federal road network across the municipality of San Juan del Rio; it can also be reached on the state road by Nopala. It has a road network of 118,960 kilometers of which 44,360 are also known as main or primary, aims specifically at serving long-distance transit, comprising two-track roads; 40,900 kilometers of state-feeding also known as secondary roads, with the main purpose of providing access to truncal roads and 33,700 kilometers of rural roads [11].

Huichapan has a location in which the tourist has different access points to the people, so it could be said that its location is somewhat privileged, as well as being the passage through the free access route to cities like Pachuca and Querétaro, generating an advantage for the municipality, to make the place known.

In general, the municipality has great natural attractions, buildings and historical monuments that remind us of important passages in our country's history. His streets, his people and his customs. Sunday tianguis offers a diversity of products in the region, so as typical gastronomy of the place. In April, the fair to the Lord of Calvary is celebrated, in which crafts, gastronomy is exposed, without failing the beautiful shows that the charity and pyrotechnics [13].

Tourism is carried out mainly in the center of Huichapan, through the main churches, chapitel and museum, with emphasis on the center, unfortunately without giving the opportunity to highlight other attractions within the municipality.

However, the municipality has a great historical wealth, which gives a pattern for tourist development in the municipality, without counting the natural and gastronomic attractions that it has and can generate projects that are interfered with to them to provide a wide range of activities where the tourist is entertained and can learn as well as to enjoy the place.

It is the responsibility of tourist actors to open tourism, facilitating infrastructure and projects involving and also benefiting from the local population, it is also important that access routes be well-established and above all good advertising campaign, with a view to publicizing the place, emphasizing its magic people's name, which would also attract more tourism to Huichapan, generating an economic spill and whether the project is being done with a good organization can also be eradicated.

\section{Tourist Resource Inventory}

One of the most important events in the history of Huichapan is 16 September 1812, when the first commemoration in the country The Scream of Independence by General Ignacio López Rayon and Andrés Quintana Roo in the Chapitel. In addition, the historic museum of Huichapan, founded by Fernando Stringuinhi Uribe, was opened on 21 November 1903, which $\mathrm{C}$ attended. Governor Quintin Rueda Villagran.

The architectural beauty admired in the St. Mateo Parish, built between the years of 1753 and 1763, under the direction of the craftsman Antonio Simon, allows us to admire two covers of Churriguerez-type pink quarry, his plant takes the form of a rubbed-covered cross divided into four parts; on the cruise, an octagonal dome is lifted to parts accused by artists who finish on a flashlight, you can also observe the paintings of the 18th century.

$\rightarrow$ Monolithic cross: unique in its gender throughout the American continent, considered as an architectural jewel made in pink quarry with well-defined engraved.

$\rightarrow$ The Chapel of Our Lady of Guadeloupe, built in the year of 1692 by the Franciscan monks.

$\rightarrow$ Chapel of the third Order, built in the year of 1563 .

$\rightarrow$ Calvary Chapel, Built in the years 1751 to 1754 .

$\rightarrow$ St. Mateo's chapel, built in the year of 1755 .

$\rightarrow$ San José Parish; a second-third atrium of the 16th century is observed.

$\rightarrow$ Municipal Palace; built of pink quarry, only work in the state, built in the year of 1887 to 1889 .

$\rightarrow$ La Casa del Diezmo; historical site known before as The Diezmo or Las Palomas.

$\rightarrow$ The Fifteen Cantera Arks at a height of 30 meters, the aqueduct crossing the famous Gallo Barranca.(Enciclopedia de los Municipios de México estado de Hidalgo, 2002). In these arches, there is a mystery cave, which appears to be a number of studies mention that it is not a natural cave because it is light all day, no matter what time of day it is, it is always lit and even no matter what the sun's position is said to be used by some ancient culture to do religious rituals.

\section{Tourist attractives}

$\rightarrow$ Sabinos ecological park, where there is a great vegetation, as well as fish. And I appreciate the nature and one of the amusements of the park, which are its hooves over 1500 years old. The park is surrounded by springs. Within the village, different types of regional cheeses are found.

$\rightarrow$ Rupestrian paintings in Boye are found on a rock wall that contains human figures and figures from various animals. 
$\rightarrow$ Regional gastronomy, in the municipality, a wide variety of carnitas and barbecue candy, milk candy, cream fatty, and craft snow produced in the center, typical carnival, due to cinnamon and tequila.

$\rightarrow$ The historical center was made of pink quarry in most construction, not to mention that the finish can be very well appreciated because architecture is still in good condition, and that the material is being worked very well in the municipality, and there is a variety of craftsmen working for it.

$\rightarrow$ Palm crafts, in the municipality, palm-made objects, such as hats, baskets, among the most popular. In addition to having articles made of ixtle, such as petates and sponges.

$\rightarrow$ Pulque, known as the drink of the gods, is very easy to find in the municipality besides finding a wide variety of cures.

$\rightarrow$ Fair for the Calvary, a patron party held after the holy weekends, which encounter various activities such as traditional dances, charred, livestock and craft exhibitions.

In addition, as an extra or supplementary, the municipality has a variety of spas, where the visitor may spend a pleasant day in the hot springs, some of them are:

$\rightarrow$ Chichimequillas, pools, green areas, camping, hot tub, massage, food sales area.

$\rightarrow$ Camino Real, thermal water pools, camping, typical food in the region.

$\rightarrow$ El Tabacal, it has shelters with hot springs and camping area.

\section{Road proposal "Ruta con historia y sabor"}

A rather extensive route could be implemented in the municipality by starting at:

Route infography, self-processing.

Within the route, there will be spaces for craftsmen working palm-made objects, where the manufacture of certain utensils such as hats, bags and baskets, and also people working on the ixtle, with products such as ayates and sponges.

As a suggestion, the route could have more influence on the dates of the "Calvario" employer, because there are more regional activities that highlight the charity, livestock and craft exhibitions and regional dances. In addition to finding various sales points for the above mentioned gastronomy.
An additional destination in the municipality and overnight

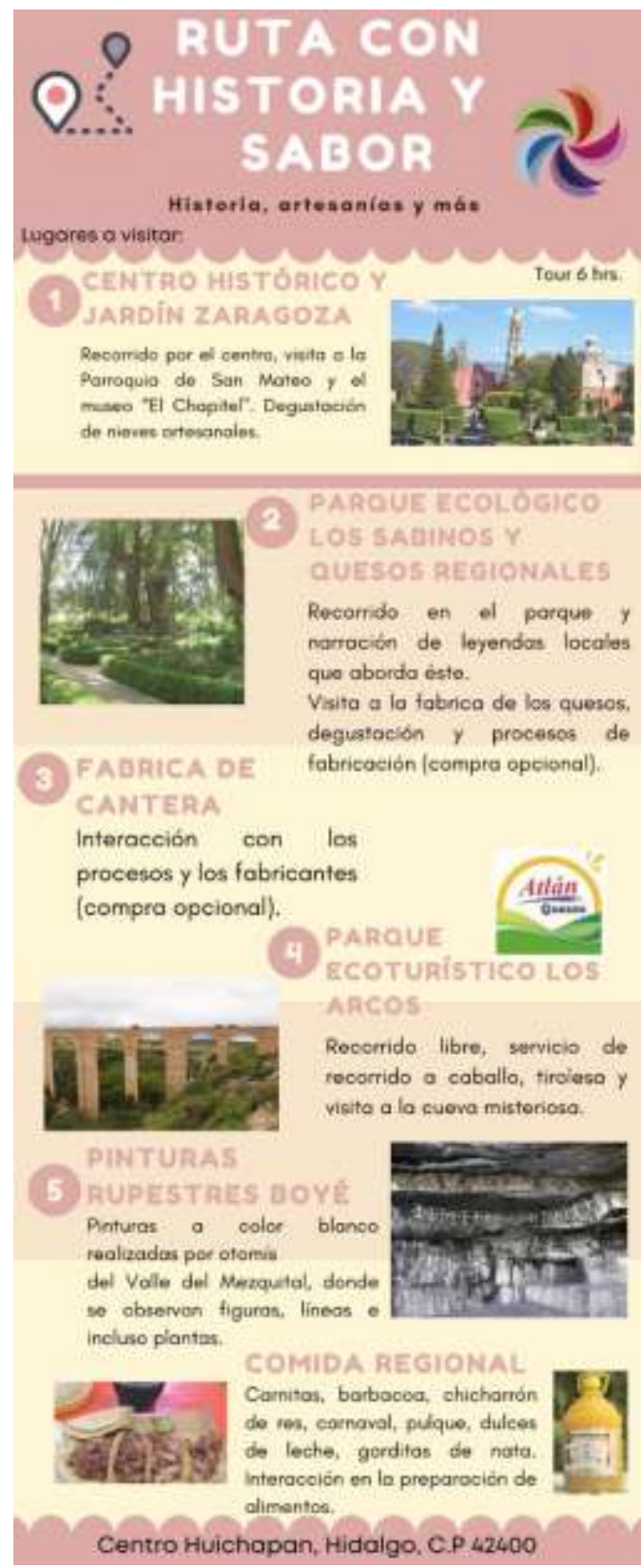

another day may be the visit to some spa that Huichapan has his pleasure in order to enjoy his spa waters.

Huichapan route 


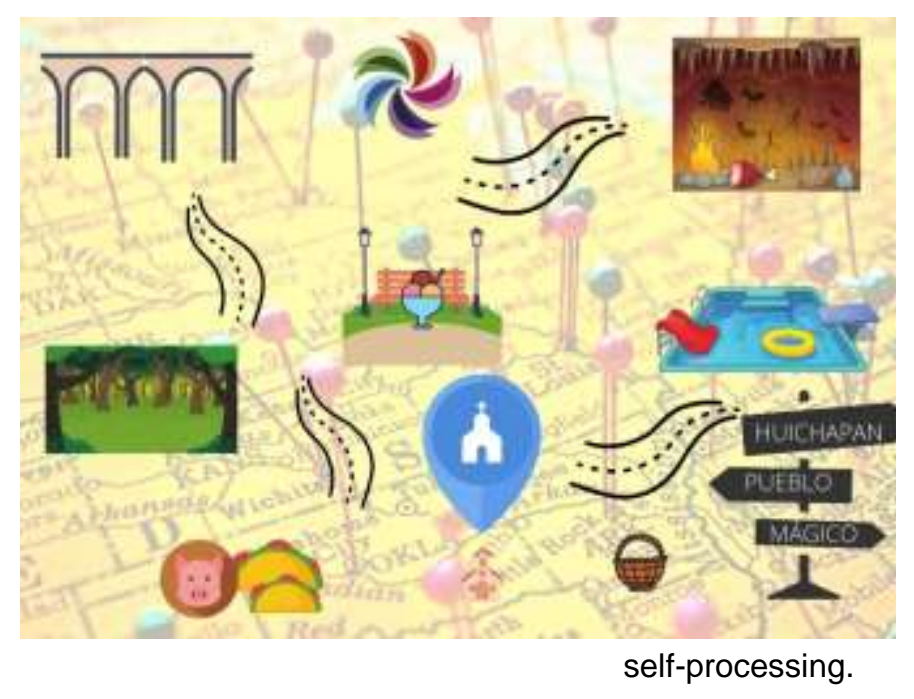

Conclusions

It is very important to carefully plan the rural tourism project that is desired in the community, otherwise the exchange rate would not have any benefit, since the activity would be over very short time. A long-term vision needs to be considered and taken of the culture of the community, as well as its participation in activities, so that they are not changing, otherwise the tourist resource would be over. In addition to maintaining its lifestyle in a way that is not altered, as tourism would be a complementary activity on a daily basis.

Rural tourism is presented in a way that broadening and diversifying productive activities within the community. The rural environment has now gained strength and has vital functions, as well as being a tourism with various uses, and taking care of natural resources in various scenarios such as protected areas, green areas, to say some of the means that characterize it.

Rural tourism is constantly moving, adapting to the needs of people. It is a sociocultural expression and also a learning, as you can observe the daily lifestyle of the community, is a space where you are they develop tourist activities which are economically rewarded.

It is important to consider the aspects of tourist influx which the community does not problem with tourists. In implementing tourist activities at a particular place, it is necessary to consider various factors such as infrastructure and loading capacity on the site, and more in the case of rural destination, since more attention must be given to these factors, otherwise harm in the community could be caused.

Huichapan has great tourist potential, in addition to carrying the magical people's name that is renowned in some way, but the local authorities have not been able to give it the right spread, and not to consider dealings with craftsmen in the village and not to have trained tourist personnel.

\section{References}

[1] OMT. (2019). UNWTO Tourism definitions. Obtenido de https://www.eunwto.org/doi/pdf/10.18111/9789284420858

[2] Fundéu. (s.f.). Fundación del Español Urgente . Obtenido de https://www.fundeu.es/recomendacion/turistificacion-neologismovalido

[3] Kieffer, M. (18 de Octubre de 2017). CONCEPTOS CLAVES PARA EL ESTUDIO DEL TURISMO RURAL COMUNITARIO. $E l$ Periplo Sustentable, 12-33. Obtenido de https://www.redalyc.org/jatsRepo/1934/193462125001/index.h tml

[4] Group, S. (19 de Noviembre de 2013). Centro del Cambio Global y la $\begin{array}{lrl}\text { Sustentabilidad, A.C. Obtenido de } & \end{array}$ http://ccgss.org/sustentabilidad/

[5] Madrid, F. (2015). La sostenibilidad en la política turística mexicana. PASOS. Revista de Turismo y Patrimonio Cultural Adventure México. (2019). Adventure México. Travel. Obtenido de https://adventuremexico.travel/estado/hidalgo/

[6] Casas, C., Soler, A., \& Pastor, J. (2012). El turismo comunitario como intrumento de erradicación de la pobreza. potencilidades para su desarrollo en Cuzco (Perú). Cuadenos de Turismo, 91108Amador, C. F., Onofre, A. A., \& Villarreal, L. Z. (3 de Julio de 2017). Universidad Autónoma del estado de Hidalgo. Obtenido de https://www.uaeh.edu.mx/scige/boletin/tepeji/n8/a19.html

[7] Amador, C. F., Onofre, A. A., \& Villarreal, L. Z. (3 de Julio de 2017). Universidad Autónoma del estado de Hidalgo. Obtenido de https://www.uaeh.edu.mx/scige/boletin/tepeji/n8/a19.html

[8] Santamaría, E., \& López-Pérez, S. (2019). Turismo Comunitario Sustentable en la Microrregión Costa Chica-Montaña, Guerrero, México. Redalyc, 2.

[9] Morelos, L. J. (4 de Octubre de 2020). La Jornada Morelos. Obtenido de

https://www.lajornadamorelos.com.mx/nacional/2020/10/04/28 384/gobierno-morelos-en-beneficio-del-turismo-rurai

[10] Gurría, Á. (3 de Mayo de 2019). OCDE. Obtenido de https://www.oecd.org/about/secretary-general/territorialreview-of-hidalgo-mexico-may-2019-sp.htm

[11] Guerrero, H. A. $(2016,2020)$. Plan Municipal de Desarrollo de Huichapan. Obtenido de plandedesarrollo.hidalgo.gob.mx Coneval, \& INEGI. (2010). SEDESOL. Obtenido de http://www.dof.gob.mx/SEDESOL/Hidalgo_029.pdf

[12] Coneval, \& INEGI. (2010). SEDESOL. Obtenido de http://www.dof.gob.mx/SEDESOL/Hidalgo_029.pdf

[13] SECTUR. (2020). Hidalgo Travel. Obtenido de https://hidalgo.travel/huichapan/ 